\title{
ポリアミドに対するアルキルモノスルホン酸 の吸着熱*
}

\author{
福井大学工学部 木村光 雄"** 山口達 ${ }^{* *}$ 郎 \\ 清水融 \\ STUDIES ON THE HEAT OF ADSORPTION OF \\ ALKYLMONOSULFONIC ACIDS ON POLYAMIDE
}

By Mitsuo Kimura, Tatsuro Yamaguchi and Toru Shimizu

(Dept. of Fibres \& Colour Chemistry, Faculty of Engineering, Fukui University. Fukui, Japan)

The heat of adsorption of alkylmonosulfonic acids $\left(\mathrm{C}_{n} \mathrm{H}_{2 n+1} \mathrm{SO}_{3} \mathrm{H}, \mathrm{n}=1 \sim 4\right)$ on polyamide was measured by the flow method at $30^{\circ}$ and $40^{\circ} \mathrm{C}$. Observed values of heat of adsorption are influenced considerably by the measured temperature and concentration of acid similarly to the case of hydrohalogenic acids (HX). From the heat of adsorption at saturated adsorption $\left(-\Delta \mathrm{H}_{\mathrm{C} \cdot \theta=1}^{\circ}\right)$ and $-\Delta \mu^{\circ}{ }_{1}$ (obtained from adsorption isotherm), the entropy change of adsorption $\left(\Delta \mathrm{S}_{\mathrm{C} \cdot 1}^{\circ}\right)$ was calculated. The value of $-\Delta \mathrm{H}_{\mathrm{C} \cdot \theta=1}^{\circ}$ decrease with increasing alkyl group in acid, and all these values are smaller than those of HX. A parameter $\left.\left(\Delta \delta=\Delta \delta_{\mathrm{H}^{+}}+\Delta \delta_{\mathrm{RSO}}\right)_{3}\right)$ which is concerned with the state of hydration of these acids in the aqueous solution was obtained from the measurement of NMR absorption spectra, and the relationship between $-\Delta \mathrm{H}_{\mathrm{C} \cdot \theta=1}^{\circ}, \Delta \mathrm{S}_{\mathrm{C} \cdot 1}^{\circ}$ and $\Delta \delta$ is discussed. Plots of $\Delta \mathrm{S}_{\mathrm{C} \cdot \mathrm{I}}$ against $\Delta \delta$ show a straight line.

Differences in $-\Delta \mathrm{H}_{\mathrm{C}, \theta=1}^{\circ}$ and $\Delta \delta$ between these acids except buthansulfonic acid correspond to those in enthalpies and entropy changes for the transfer of normal aliphatic hydrocarbons $\left(C_{n} H_{2 n+2}, n=1 \sim 3\right)$ from the liquid state to the aqueous solution at $25^{\circ} \mathrm{C}$, respectively.

From these results, it is assumed that the process of dehydration of these acid anions is an important factor for the adsorption of alkylsulfonic acids on polyamide similarly to the case of HX, and in these cases, differences in $\Delta \mathrm{S}_{\mathrm{C}}^{\circ}$. $_{\mathrm{I}}$ correspond with those in the interaction of alkyl group in acid anions with water. It is also assumed that $\Delta S_{\mathrm{C} \cdot \mathrm{I}}^{\circ}$ of these acids are positively larger than those of $\mathrm{HX}$ and $-\Delta \mathrm{H}_{\mathrm{C} \cdot \theta=1}^{\circ}$ decrease by the decrease of the structure of water with dehydration of alkyl group.

(Received January 14, 1974)

\section{1. 緒言}

ポリフミトに対する酸性染料の吸着機满を詳細に考察 する為，まず前報”までにおいて酸性染料のモデル化合 物としてハロゲン化水素酸の吸着䓡を流動法によって測 定した。吸着量と㖟着熱量との関俰から飽和吸着に㧍け る吸着熱 $\left(-\Delta H_{C \cdot \theta=1}^{\circ}\right)$ を得, この值と等温平衡吸着案験 結果から得た標準親和力とから吸着の標準エントロピー 変化の值を求め, NMR吸収スベクトルの測定から得た

*この報文を「流動法による吸着の測定に関する研究 (第 5 報)」「Studies on the measurement of adsorption by flow method (part5)」とする。

**現在の所属, 京都工芸緎維大学工芸学部色染工芸教 室, 京都南左京区松ヶ崎御所海道町
これらの酸の水和の状態を示すバラメーター( $\Delta \delta)$ との 関連を検討した。その結果，標準エントロピー変化 $\left(\Delta S_{C}^{\circ} . I\right)$ が $\Delta \delta$ 值と良く対応することから，八ロゲン化水素酸の 種類による $\Delta S_{C . I}^{\circ}$ ならびにー $\Delta H_{C . \theta=1}^{\circ}$ の值の差はそれぞれ の酸アニオンの吸着に際しての水中からの脱離のしやす さの差に対応し，その酸アニオンが水構造破堙性である (本中からの脱離が容易である) ほど $\Delta S_{C}^{0}$. 值は小さくな り, 従ってー $\Delta H_{C \cdot \theta=1}^{\circ}$ 值は大さくなるのであるうと推定し たo

本報においては，八ロゲン化水素酸よりも実際の酸性 染料に近く，しかもイオン解離度の大きいもデル化合物 として 2,3 アルキルモノスルホン酸を使用して前報 までと同様に吸着熟の测定ならびにNMR 吸収スべクト ルの測定，等温平衡吸着の測定を行ない，それらの結果 
からポリアミドへの吸着と酸の水和状㮩との関連，アル キル基の影響などについて検討した。

\section{2. 試料およひ実験の方法}

2.1 試 料

ボリアミド武料：和光純薬製カラムクロマトグラフィ 一用ポリフミドC -200 粉末 $(150$ メッシニ以上)，フミ ，来端基当量 $7.49 \times 10^{-5} \mathrm{eq} / \mathrm{g}^{2)}$ 。

酸試料：メタンスルホン酸、エタンスルホン酸(いず れも市肘特級試菜)，プロパンスルホン酸，ブタンスル ホン酸(いずれもイーストマン・コダック社製試楽)。

NMR 吸収スペクトル湘定用試薬： $\mathrm{D}_{2} \mathrm{O}(99.75 \not) ）$ ，

TMS (Tetramethylsilane)〈いずれもィルク社製䟼 薬)。

\section{2 吸着熱の測定}

日本電子製熱検出型自動記録液体クロマトグラフィー JLC-2Aを改良し流動败少熱計として使用し，30

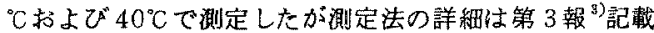
のとおりである。

な抢，等温平衡吸着聿験は通常の残浴滴定法によって 行ない48時間後の吸着量を決定した。

\subsection{NMR昅収スペクトルの測定}

前報”と同様に $\mathrm{D}_{2} \mathrm{O}-\mathrm{H}_{2} \mathrm{O}$-酸系に扔引る NMR吸収スへ クトルを測定し，酸の濃度変化による水プロトンの化学 シフトの変化加らそれぞれの酸の水和の状熊に対位する パラメーター $\Delta \delta$ (客液 $1 \mathrm{~kg}$ 中に扔ける酸 $1 \mathrm{~mol}$ 当りの水 プロトンの化学シフト变化率)を求めた。 $\Delta \delta$ 值はいずれ も酸のプロトンとアニオンの両者についての値を合わせ たものであり，高磁場側への变化を十，低磁場側への変 化を一として表示した。一般に一の値が大きい程水和は 强く起っていることを示している”。測定は日本電子製高 分解能NMR装置 JNM-4H-100型在使用し，TMSを 外部基準としていずれも $24^{\circ} \mathrm{C} て ゙$ 行なった。

\section{3. 結果と考察}

得られた吸着熱測定値はハロゲン化本素酸などの場合 と同じく吸着した酸の濃度，吸着温度等によって異なる。 図 1 に吸着濃度 $(\theta=$ 吸着量 /館和吸着量) と吸着熱测定 值 $\left(-\Delta H_{C}^{a}\right)$ との関係の例を示したが，これらのダラフの 傾向は比較の為に加えた HClの場合”と同様である。グ ラフを $\theta=1$ に外插して飽和吸着における吸着熱量 $(-\Delta$ $H_{C \cdot \theta=1}^{\circ}$ )求め，別に行なった等温平衡吸着実験の結果 から標準親和力 $\left(-\Delta \mu \mu^{\circ}\right)$ を得てこの両者から標準エント ロピ一変化 $\left[\Delta S_{C \cdot I}^{\circ}=\left(\Delta H_{C \cdot \theta=1}^{\circ}-\Delta \mu_{I}^{0}\right) / T\right]$ 算出した。こ れらの値を表 1 にまとめて記載した。

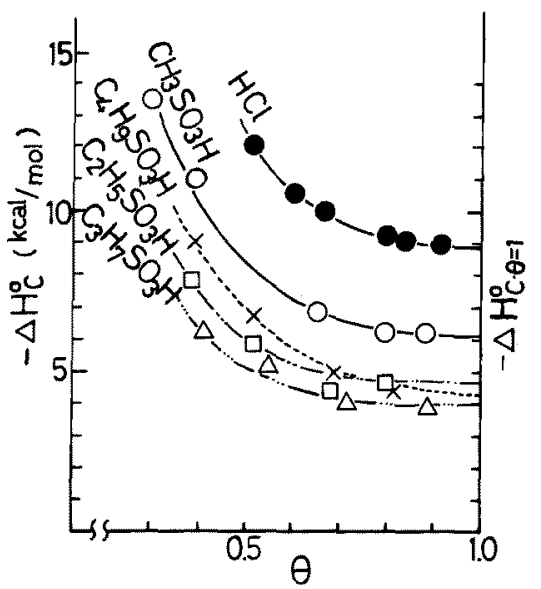

Fig. 1 The relationship between $-\Delta \mathrm{H}_{\mathrm{C}}^{\circ}$ and $\theta$ and $-\Delta \mathrm{H}_{\mathrm{C} \cdot \theta=1}^{\circ}$ at $40^{\circ} \mathrm{C}$.

Tabie 1 Observed values

\begin{tabular}{|c|c|c|c|c|c|}
\hline Acid & $\begin{array}{c}T \\
\left({ }^{\circ} \mathrm{C}\right)\end{array}$ & $\begin{array}{c}-\Delta H_{C \cdot A=1}^{\circ} \\
\text { (kcal } \\
\text { mol) }\end{array}$ & $\begin{array}{c}-\Delta \mu_{I}^{\circ} \\
(\mathrm{kcal} / \\
\text { mol })\end{array}$ & $\begin{array}{l}\Delta S_{C \cdot I}^{\circ} \\
\mathrm{cal} \\
\mathrm{mol} \cdot \mathrm{deg}\end{array}$ & $\begin{array}{c}\Delta \delta \\
\left(24^{\circ} \mathrm{C}\right)\end{array}$ \\
\hline \multirow{2}{*}{$\mathrm{CH}_{3} \mathrm{SO}_{3} \mathrm{H}$} & 30 & 4.2 & 10.4 & 20.7 & \multirow{2}{*}{-0.310} \\
\hline & 40 & 6.1 & 10.2 & 13.1 & \\
\hline $\mathrm{C}_{2} \mathrm{H}_{8} \mathrm{SO}_{3} \mathrm{H}$ & 40 & 4.7 & 10.3 & 17.9 & -0.380 \\
\hline \multirow{2}{*}{$\mathrm{C}_{3} \mathrm{H}_{7} \mathrm{SO}_{3} \mathrm{H}$} & 30 & 2.9 & 10.4 & 24.8 & \multirow{2}{*}{-0.420} \\
\hline & 40 & 4.0 & 10.5 & 20.8 & \\
\hline $\mathrm{C}_{4} \mathrm{H}_{8} \mathrm{SO}_{3} \mathrm{H}$ & 40 & 4.3 & 10.4 & 19.5 & -0.400 \\
\hline
\end{tabular}

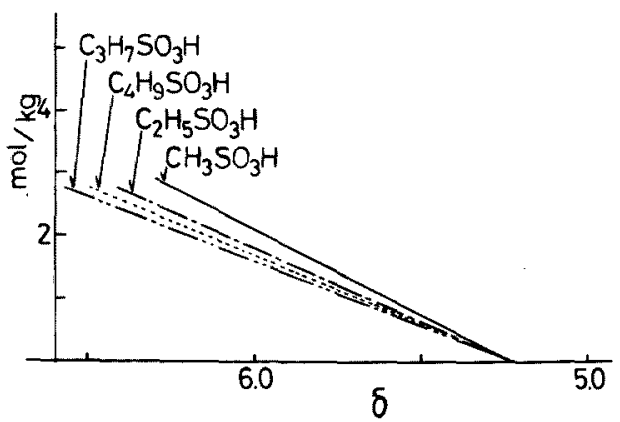

Fig. 2 The chemical shift change of water proton with concentration of acid at $24^{\circ} \mathrm{C}$.

つぎにNMR吸収スべクトル測定結果を図2に示す。 得られた值線から求めた $\Delta \delta$ 値は表 1 に記載したとお りである。

表 1 に記載した結果を検討してみると，同じ温度にお いてスルホン酸のアルキル基が大きくなるにつれてーム $H_{C . \theta=1}^{\circ}$ の值は小さくなり，従って $\Delta S_{C . I}^{\circ}$ は大きな正の值 を示している。また $\Delta \delta$ 值の負の㛹も大きくなるが，い 
ずれの場合もブタンスルホン酸の值はェタンスルホン酸 とプロパンスルホン酸の間の值を与えている。 $\Delta S_{C .1}^{0}$ は 大さな正変化を示しているが，図 3 に示すように $\Delta \delta$ 值 と良く対応し、アルキル基を含むスルホン酸アニオンの 水との相互作用の大きさが吸着系のエントロピー変化に 関与していることを示している。

そこでアルキル基の影笪について考えるため, Némethy ら“の報告しているアルカン類の純夜体状態から水溶

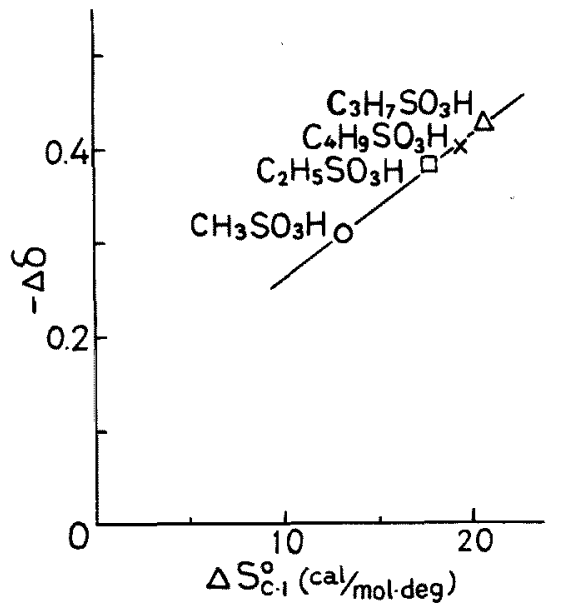

Fig. 3 The relationship between $\Delta \mathrm{S}_{\mathrm{C} \cdot \mathrm{I}}^{\circ}$ and $\Delta \delta$.

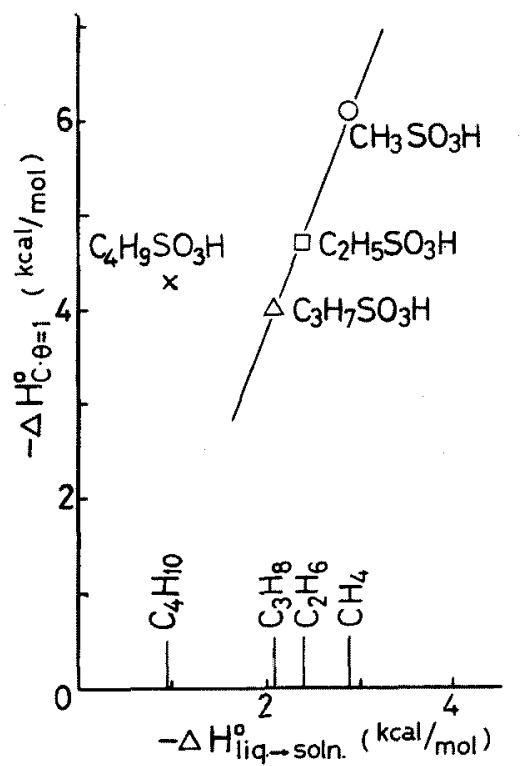

Fig. 4 The relationship between $-\Delta \mathrm{H}_{\mathrm{C} \cdot \mathrm{g}=1}^{\circ}$ at $40{ }^{\circ} \mathrm{C}$ and $-\Delta \mathrm{H}_{\mathrm{liq}}^{\circ} \rightarrow$ soln (enthalpy for the transfer from the liquid to aqueous solution) at $25^{\circ} \mathrm{C}$.

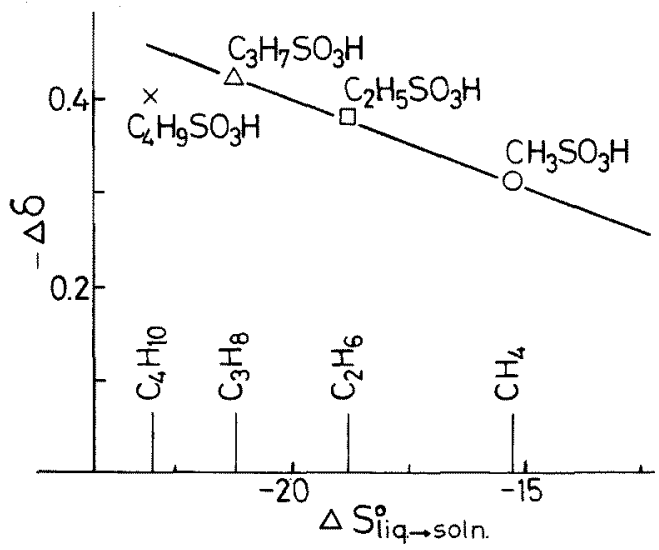

Fig. 5 The relationship between $\Delta \delta$ at $24^{\circ} \mathrm{C}$ and $\Delta \mathrm{S}_{\text {liq } \rightarrow \text { soln. }}^{\circ}$. (entropy change for the transfer from the liquid to aqueous solution) at $25^{\circ} \mathrm{C}$.

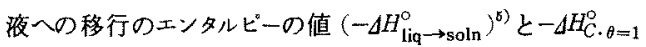
との関俰挹よび同じ移行のニントロピー变化 $\left(\Delta S_{\mathrm{liq} \rightarrow \mathrm{son}}^{\circ}\right)^{6)}$ と $\Delta \delta$ との関䋆を調べてみるとそれでれ四 4 および图 5 に示すようにブタンスル壮ン酸の場合を除いていずれも 良い直線関倸を与える。

これらの結果から，次のような推定をすることが出来 よう。すなわち， $\Delta \delta$ 値は前報1でも述べたように酸のブ ロトンおよびアニオンの水和の状態に対応するパラィー ターを合わせたものであり，プロトンの作用を同じとみ ると各酸間の $\Delta \delta$ 值の差は各イオン間の水との相互作用 の強さの差に対応する。これは図 5 の $\Delta S_{\mathrm{liq} \rightarrow \text { soln }}^{\circ}$ との関 俰からブチル基の場合を除いて酸てニオン中のアルキル 基閒の水との相互作用の差に対応する。 $\Delta \delta$ 值は図 3 に 示すように $A S_{C . I}^{\circ}$ とも対応するものであるから，全体と して考えると、これらの吸着系において酸アニオン中に 含まれるアルキル基の水中からの脱㰚のしやすさの差が 吸着系全体のエントロピー变化の差に対応し, 從って吸 着熱量の差に対応する。例えば同じ温度に括けるメタン スルホン酸とプロパンスルホン酸の場合を比較してみる とそれぞれの酸アニオン中に含まれるメチル基とブロピ ル基とではプロピル基の方が水との相互作用が大きく $\Delta \delta$ の一值が大であって，吸着に祭してはメチル基を有する

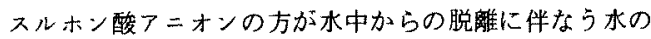
構造変化の影響が少なく吸着系のエントロピ一変化は小 となって吸着熱は大となるのであるう。ブタンスルホン 酸の場合はフルキル基が長くなることによる水中での挙 動の違いなどプロパンスルホン酸までのアルキルモノス ルホン酸とは異なった要因加加わって来るのであるらと 考えられるが，これについては今後検討する予定である。 
つぎに，フルキルモ，スルホン酸の場合を前報 ${ }^{1)}$ のロ ゲン化水素酸の場合と比較してみると，一般にーA的の 値はあまり造わないがー $\Delta H_{C . \theta=1}^{\circ}$ の值は小さく従って $\Delta S_{C . I}^{\circ}$ は大きな正の值を与える。この違いは先にも述べたよう にスルホン酸アニオン中に含まれるアルキル基が水の棈 造性に極めて强い影留をるぼしているからであると考光 られ，スルホン酸アニオンとハライドアニオンとを比較 する為には何らかの方法でアルキル基の影響を消去しな ければならない。そこで仮に1つの方法としてフルキル 基を含まないスルホン酸 $\mathrm{HSO}_{3} \mathrm{H}$ を想定してみる。この スルホン酸のプロフィールを他の実祭のアルキルモノス ルホン酸のデータから推定してみると, 各酸のフルキル 基の×チレン基 1 個当りの值をそれぞれのー $4 H_{C .}^{\circ} a=1$,

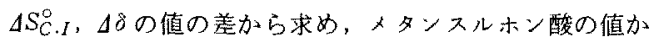
豆差引くことによって， $-\Delta H_{C \cdot \theta=1}^{\circ}=7.2 \mathrm{kcal} / \mathrm{mol}$, $\Delta S_{\mathrm{C} . I}^{\circ}=9.2 \mathrm{cal} / \mathrm{mol} \cdot \mathrm{deg}\left(\right.$ いずれも $\left.40^{\circ} \mathrm{C}\right)$ 括よび $\Delta \delta=$ $-0.260\left(24^{\circ} \mathrm{C}\right)$ という值が得られる。これらの值を例え ば同じ温度に拈けるHC1の場合の值 ${ }^{1)},-\Delta H_{C, \theta=1}^{\circ}=8.9 \mathrm{kcal}$ $/ \mathrm{mol}, \Delta S_{C \cdot 1}^{\circ}=5.4 \mathrm{cal} / \mathrm{mol} \cdot \mathrm{deg}$ (いずれも $40^{\circ} \mathrm{C}$ )、, $\Delta \delta$ $=-0.495\left(24^{\circ} \mathrm{C}\right)$ と比較すると，A值の一の值がかなり $\mathrm{HCl}$ よりさいにも拘わらず $\Delta S_{\text {C.I }}^{\circ}$ はHClより大きな正 の値を与え，一 一 $H_{C . \theta=1}^{\circ}$ の值は小さくなっている。この善 については今後换討寸る予定であるが， $\mathrm{Cr}$ とオキシ酸 である $\mathrm{HSO}_{3}^{-} と の$ 我和の形態の違いなども考えら机るで あるう。

\section{4. 総括}

アルキルモノスルホン酸のホりアミトに対する吸着熱

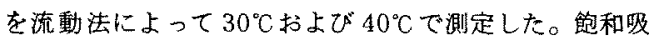
着に招ける吸着熱量一 $-\Delta H_{C \cdot \theta=1}^{\circ}$ を求如，これを通常の级 着実験に坊いて用いられる吸着熱上同様に取报い，別途

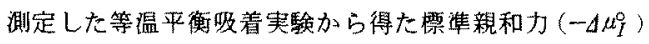
と加ら吸着系全体の標集エントロビ一变化 $\left(\Delta S_{C . I}^{\circ}\right)$ を算 出した。さらにNMR吸収スペクトルの楖定からこれら

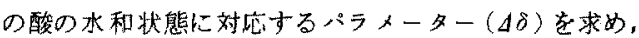
前報 ${ }^{1}$ と同様にこれらの值の間の関連について検討した。 用いたメタンスルホン酸〜ブタンスルホン酸のうち， ブタンスルホン酸の場合を除いて, 各々の酸の間のーA

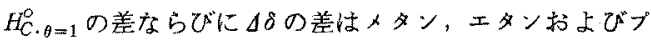
ロ ゚ンの純液体状態加ら水溶夜中へ移行する祭のエンタ ルピーの差ならびにェントロピーの差とそれぞれ良く对

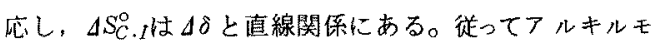
ノスルホン酸類のボリフミドに対する吸着にはハロゲン 化水素酸の場合と同じく水の構造变化を伴なった酸の水 中からの脱雄過程が強い影響を及ぼし，これらの酸の $-\Delta H_{C . \theta=1}^{\circ}, \Delta S_{C . I}^{\circ}, \Delta \delta$ 值の差は酸アニオン中に念まれる アルキル基の水との相互作用の強さの差に対応すると推 定される。また，これらのアルキル基が水中から脱離す る際に引き起す水の構造性の減少が吸着系全体に強く作 用し，八ロゲン化本素酸の場合と此較して大きな標準工 ソトロビーの増加をもたらし，吸着熱量を城少せしめる のであるらと考えられる。

本研究は第 15 回染色化学討論会 (1973) 東京および 絿維学会昭和 48 年度秋李研究発表会 (1973) 福并にお いて発表したものである。また，本研究の研究費の一部 は昭和 47 年度実吉研究助成金によったことを付記し謝 意を表する。

\section{文献および註}

1) 木村光婎, 山口達郎, 谷口哲婎, 清水融; 繊学誌, 30, $\mathrm{T}-544(1974)$

2）第 3 報量においてPA-A試料として使用したもの。

3) 木村光雄, 高橋哲夫, 谷口哲雄, 清水 融; 緎学誌, 28, 265(1972)

4) G.Némethy,H.A.Scheraga; J.Chem. Phys, 36, 3401(1962)

5）奏験値として報告している值の上限徝。

6)この場合実鈳值ではバランキが大きいので計算値と して挙げている倠を使用した。 